\title{
Review on hybrid energy systems for wastewater treatment and bio-energy production
}

\author{
Pei Fang Tee ${ }^{a}$, Mohammad Omar Abdullah ${ }^{\mathrm{a}, *}$, Ivy Ai Wei Tan ${ }^{\mathrm{a}}$, \\ Nur Khairunnisa Abdul Rashid ${ }^{\mathrm{b}}$, Mohamed Afizal Mohamed Amin ${ }^{\mathrm{a}}$, \\ Cirilo Nolasco-Hipolito ${ }^{c}$, Kopli Bujang ${ }^{c}$ \\ a Department of Chemical Engineering and Energy Sustainability, Faculty of Engineering, Universiti Malaysia Sarawak (UNIMAS), 94300 Kota Samarahan, \\ Sarawak, Malaysia

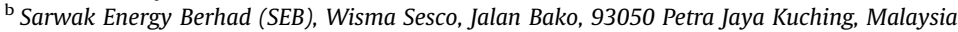 \\ ${ }^{\mathrm{c}}$ Faculty of Resource Science E Technology, Universiti Malaysia Sarawak (UNIMAS), 94300 Kota Samarahan, Sarawak, Malaysia
}

\section{A R T I C L E I N F O}

Article history:

Received 5 August 2015

Received in revised form

25 September 2015

Accepted 10 October 2015

Available online 11 November 2015

Keywords:

Bioenergy

Hybrid energy

Wastewater treatment

\begin{abstract}
A B S T R A C T
Access to clean water has been a great challenge around the globe due to the high pollutant contents in the water. Therefore, there is a high demand of freshwater resources or a dire need of clean recycle wastewater as a new source of water supply. In order to accomplish this, new concept or engineering systems need to be developed where hybrid wastewater treatment system can be an effective pollutants removal. Wastewater contains energy in the form of biodegradable organic matter. The concept of accomplishing wastewater treatment and generate energy simultaneously has been a trend recently and can be done with hybrid wastewater treatment system. Energy gained from such hybrid system is therefore both sustainable and environmental friendly which may be good source of bio-energy to compliment the power of a treatment plant. In this paper, we classify hybrid wastewater systems typically include physical-biological hybrid, physical-chemical hybrid, chemical-biological hybrid and physical-chemical-biological hybrid system. From the detailed literature gathered thus far, hybrid systems demonstrated some potential advantages compared to stand-alone systems such as: more stable and sustainable in the voltage generated, better overall treatment efficiency and energy savings.
\end{abstract}

(c) 2015 Elsevier Ltd. All rights reserved.

\section{Contents}

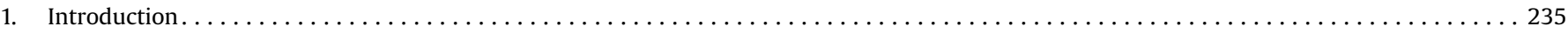

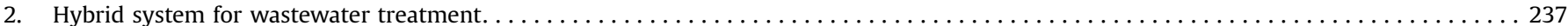

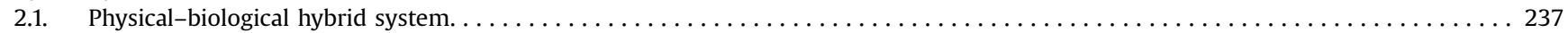

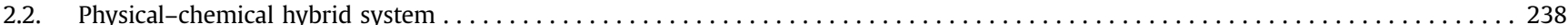

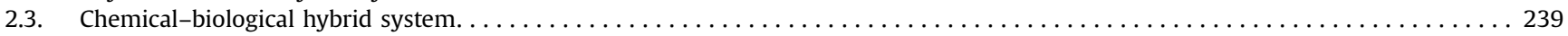

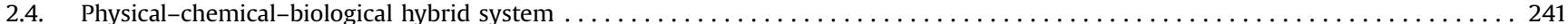

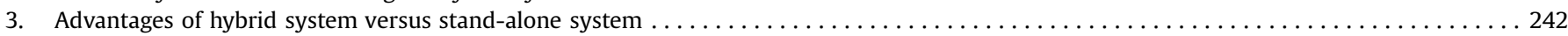

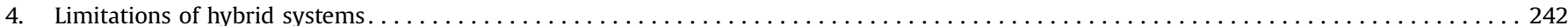

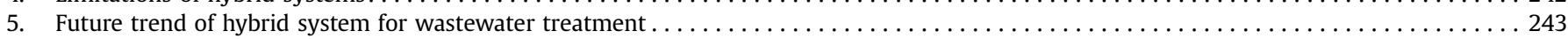

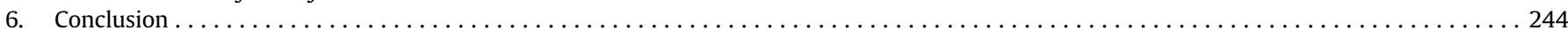

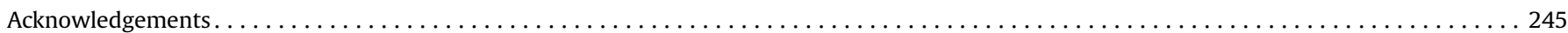

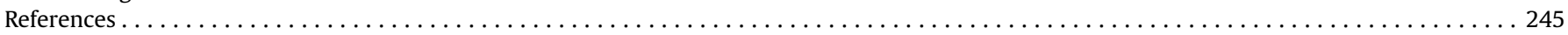

\footnotetext{
* Corresponding author. Tel.: +60 82583280 (direct line); fax: +60 82583409.

E-mail addresses: amomar13@gmail.com, amomar@feng.unimas.my, amomar@unimas.my (M.O. Abdullah).
}

\section{Introduction}

Water becomes the scarcest thing in some parts of the world as the availability is becoming limited due to the increasing 